\title{
Professionalizing bureaucracy and building state capacities: are there unequal advances in Brazilian public administration?
}

\author{
Ciro Campos Christo Fernandes 1 \\ Pedro Lucas de Moura Palotti 12 \\ 1 Escola Nacional de Administração Pública / Diretoria de Pesquisa e Pós-graduação stricto sensu, Brasília / DF - Brazil \\ 2 Instituto Brasiliense de Direito Público / Escola de Direito e Administração Pública, Brasília / DF - Brazil
}

\begin{abstract}
This article contributes to the discussion on public administration in Brazil. It examines the differences between the four functions of the state (basic functions, welfare, infrastructure and development, and emerging functions), based on the positions and careers of public servants. The data were collected in 2014 using a survey with public managers from different agencies of the Brazilian federal administration. The results point to distinctions regarding the roles played by middle managers, considering their distribution by state functions, profile, and activities. In a historical perspective, although there are basic functions that constitute the state, the creation of new careers and the recruitment of staff in the bureaucracy resulted in unequal development of the different state functions, generating imbalance and asymmetries. Also, emerging functions are generating new, more flexible, and dynamic ways for managers to work, which have renewed the Brazilian bureaucracy, albeit in a limited and heterogeneous way.

Keywords: bureaucracy; State capacity; State functions; Brazilian public administration.
\end{abstract}

\section{Profissionalizando a burocracia e construindo capacidades: avanços desiguais na administração pública brasileira?}

Este artigo contribui para a discussão sobre a administração pública no Brasil examinando as diferenças entre as quatro funções estatais - funções básicas, bem-estar, infraestrutura e desenvolvimento e funções emergentes - com base nos cargos e nas carreiras dos servidores públicos. Os dados foram coletados em 2014, por meio de pesquisa com gerentes públicos de diferentes órgãos da administração federal. Os resultados apontam distinções relativas aos papéis desempenhados pelos gerentes de médio escalão, considerando sua distribuição por funções estatais, perfil e atividades que realizam. Em uma perspectiva histórica, embora existam funções básicas que constituem o Estado, a criação de novas carreiras e o recrutamento de quadros de pessoal na burocracia têm contemplado as diferentes funções estatais de forma desigual, gerando desequilíbrios e assimetrias. Por outro lado, funções emergentes vêm gerando novas formas, mais flexíveis e dinâmicas, de atuação dos gerentes - que têm renovado a burocracia brasileira, ainda que de modo limitado e heterogêneo.

Palavras-chave: burocracia; capacidade do Estado; funções de estado; Administração pública brasileira.

\section{La profesionalización de la burocracia y la creación de capacidades: ¿Avances desiguales en la administración pública brasileña?}

Este artículo contribuye a la discusión sobre la administración pública en Brasil al examinar las diferencias entre las cuatro funciones estatales: funciones básicas, bienestar, infraestructura y desarrollo y funciones emergentes, basadas en las posiciones y carreras de los funcionarios públicos. Los datos se recopilaron en 2014, mediante una encuesta con gerentes públicos de diferentes órganos de la administración federal. Los resultados señalan distinciones con respecto a los roles que desempeñan los gerentes intermedios, considerando su distribución por funciones estatales, perfil y actividades que realizan. En una perspectiva histórica, si bien existen funciones básicas que constituyen el Estado, la creación de nuevas carreras y el reclutamiento de personal en la burocracia han considerado las diferentes funciones estatales de manera desigual, generando desequilibrios y asimetrías. Por otro lado, las funciones emergentes generaron formas nuevas, más flexibles y dinámicas de desempeño de gestión que renovaron la burocracia brasileña, aunque de una manera limitada y heterogénea.

Palabras clave: burocracia; capacidad Estatal; funciones Estatales; administración pública brasileña.

DOI: http://dx.doi.org/10.1590/0034-761220180072x

Article received on March 10, 2018 and accepted on October 18, 2018.

ISSN: $1982-3134$ (c) (1)

[Original version] 


\section{INTRODUCTION}

The current structure and organization of public administration in Brazil was designed during the political process of transition from the authoritarian-modernizing regime of 1964-1985 to democratization. It was accompanied by comprehensive legal and regulatory definitions established by the Constitution of 1988. This article aims to identify and analyze the recent changes and trends regarding recruitment, development, and training in public administration that influence the appointment of managerial positions in the intermediate levels of the federal administration.

This article was based on a theoretical construction of state capacities through which it is possible to set categories for comparative analysis between sectors. It adopts an analytical framework based on a historical-structural typology of state functions and their governmental tasks. This typology considers that the construction of the state is the outcome of a cumulative (not necessarily linear) process of building state capacities that are shaped inside the public administration. These capacities can be analyzed and categorized into four state functions: the basic or core functions, which make up the so-called "state-minimum"; infrastructure and development functions; welfare functions; and emerging functions, the latter constituting the new developmental state.

Recently, a bulk of studies started to focus on public bureaucracy given new datasets, such as the public information about socioeconomic characteristics of the civil servants in the Transparency Portal of the Brazilian Federal Government. This renewed academic interest can be divided into two set of studies.

The first one was based on the relationship between politics and public administration, emphasizing the dynamic of coalitions in the Brazilian multiparty presidential system as a key variable to understand political instability and turnover in the public administration at the federal level (Barberia \& Praça, 2014; Lopez, Bugarin, \& Bugarin, 2015; Lopez \& Praça, 2015; Praça, Freitas, \& Hoepers, 2012). The second was dedicated to study the federal public administration for long periods of time, exposing how the federal workforce was rebuilt in the last decade, as an effort to reorganize federal careers and create new ones to promote state capacities, mainly in the social area (Cavalcante \& Carvalho, 2017; Palotti \& Freire, 2015).

After this brief introduction, the article discusses the literature adopting a structural-historical perspective to study the state functions. The main arguments focus on how national states evolve assuming different configurations as they expand their functions and activities to face the challenges of social and economic development, which is an approach that can be applied to Brazil. This article proposes an analytical frame to understand recent tendencies in the recruitment of civil servants and the creation of careers. The division of different state functions followed previous work carried out by Fernandes (2015) from which this theoretical framework was based. Section 3 introduces the methodology applied to the empirical research. The most important qualities of Brazilian federal government managers are presented and discussed in section 4 , with a focus on the profile, professional performance, organizational perceptions, and common interactions with stakeholders. Finally, the conclusion is presented in section 5 . 


\section{STATE FUNCTIONS AND CAREERS IN THE PUBLIC SECTOR: THEORETICAL FOUNDATIONS AND SOME IMPLICATIONS FOR BRAZIL}

The historical configuration of the state shall determine different organizational structures and processes in the public administration. State history follows an evolutionary path with challenges or "tasks" that demand capacity building from the public administration. The typology presented in Box 1 considers three steps, referring to the work of Weiss and Robson (1998). The evolution of public administration is related to the configurations of the state. Each historical configuration is associated with a dominant role and the respective "tasks" to be performed by public administration. The development of emerging functions imposes new challenges which require capacity building and new structures and processes within the public administration.

BOX 1

CONFIGURATIONS OF THE STATE, FUNCTIONS, "TASKS” AND CAPABILITIES

\begin{tabular}{|c|c|c|}
\hline State's historical configuration & $\begin{array}{l}\text { State functions } \\
\text { "Tasks" of public administration }\end{array}$ & $\begin{array}{c}\text { Types of capabilities } \\
\text { Public administration capabilities }\end{array}$ \\
\hline Despotic or absolutist state & Basic or core functions (typical) & $\begin{array}{l}\text { Core capabilities } \\
\text { Tax collection }\end{array}$ \\
\hline Liberal state & $\begin{array}{l}\text { Administration of the state central } \\
\text { apparatus }\end{array}$ & $\begin{array}{l}\text { Control } \\
\text { Staffing } \\
\text { Enactment of laws and norms }\end{array}$ \\
\hline $\begin{array}{l}\text { Welfare state } \\
\text { Developmental state }\end{array}$ & $\begin{array}{l}\text { Infrastructure and economic } \\
\text { development }\end{array}$ & $\begin{array}{l}\text { Capacity for decision making and } \\
\text { management of production and services } \\
\text { Planning and projects }\end{array}$ \\
\hline & $\begin{array}{l}\text { Social welfare } \\
\text { Management of the extended } \\
\text { functions }\end{array}$ & $\begin{array}{l}\text { Budget programming } \\
\text { Human resources management } \\
\text { Information systems } \\
\text { Organizational designing }\end{array}$ \\
\hline $\begin{array}{l}\text { Coordinator or "facilitator" } \\
\text { state }\end{array}$ & Emerging functions & $\begin{array}{l}\text { Capabilities for coordinating networks of } \\
\text { public governance }\end{array}$ \\
\hline Neo-developmental state & Coordination of public policies & $\begin{array}{l}\text { Strategic planning } \\
\text { Negotiated allocation of public resources } \\
\text { Accountability and control over results } \\
\text { Organizational and process integration }\end{array}$ \\
\hline
\end{tabular}

Source: Elaborated by the authors.

In the absolutist (16th and 18th centuries) and liberal (19th and 20th centuries) eras, the dominant functions performed by the public administration were related to the effectiveness of its central apparatus and were based on the broad autonomy of the state bodies (Tilly, 1975; Mann, 1988). The 
subsequent step led to the development of interactive relations with society, accompanying the higher technical and operational complexity of tasks. The functions developed in this step are related to the emergence of the expanded state, which historically assumes the form of so-called welfare state and/ or developmental state, from the end of the 19th century and especially after 1945, following different national paths (Evans, Rueschmeyer, \& Skocpol, 1985; Leftwich, 1995).

The third step is represented by the emerging forms of the state, since the end of the 20th century: the coordinator or "facilitator" state. This contemporary form can be associated with the construction of the governance arrangements, based on growing interdependence between state and society and the expansion of the non-state public sector (Peters \& Pierre, 1998; Milward \& Provan, 2000). In this context, the capacity for coordination of the state tends to become an increasingly present challenge.

The typology is completed with a categorization of state capacities linked to the historical forms of state and their functions performed by public administration. The typology proposal includes the following capabilities historically outlined: basic capabilities belonging to the "core" functions of the state; capabilities related to decision-making processes and management of production and services and finally, capabilities of coordinating with other actors outside the state in contexts of advanced governance. The core capabilities are developed while the essential structures of the state are being shaped, its autonomy strengthened and its differentiation from society grows. The mechanisms to build capacities are those classically found in public administration organized as a bureaucracy (Fukuyama, 2013; Kjaer \& Hansen, 2002).

The capabilities linked with the expanded state are related to the management of processes and systems that get increasingly complex as decision making requires technical expertise. The development of these capabilities meets the needs of the state to perform planning, coordination, and management of services that are expanding within the welfare and developmental states. The theoretical approaches of public administration that criticize bureaucracy and propose its flexibilization discuss the performance aspects regarding this form of the state (Bresser Pereira, 1998, 2004; Ormond \& Löffler, 1999).

The emerging capabilities deal with accountability, participatory deliberation and consensusbuilding, and they are focused on the coordination between state and other actors operating in the public sector. They are associated with new forms of networked organizations, partnership arrangements and the proliferation of public entities acting through mutual coordination. To a large extent, the requirements and mechanisms associated with the state as coordinator are discussed by the literature on governance (Levi-Faur, 2011; Mattews, 2012; Riain, 2004).

The steps of this typology should not be considered isolated but cumulative so that the construction of the capacity of the center of government in the first step is a requirement for subsequent ones and there are dependence relations established as a consequence of the path taken: the same capacity develops and possibly becomes more complex in the next step. This development can be accomplished in each area of the state. Therefore, the proposed categorization suggests that the organization and performance of public administration may depend on a combination of "traditional" and emerging capabilities. 


\subsection{Expansion of the state and recruitment of civil servants}

The results of the recent expansion of the Brazilian state can be viewed in aggregate numbers of the inflow of civil servants in the federal administration (see Table 1). The numbers refer to the distribution of civil servants by state functions and specific activities during the period 1995-2014. The inflow presented in the table is categorized in basic or typical state functions, infrastructure and economic development, social welfare, and emerging functions. As mentioned, this last category is constituted by the new functions that are emerging as a result of ongoing transformations in the role and way of acting of the state. The distribution is based on the categorization of positions and careers by state function presented in Fernandes (2015, pp. 15-18).

\section{TABLE 1 THE INFLOW OF CIVIL SERVANTS IN FEDERAL ADMINISTRATION, BY STATE FUNCTION - 1995-2014}

\begin{tabular}{|c|c|c|}
\hline State functions / Activity & $\begin{array}{c}\text { Quantity } \\
\text { (1) }\end{array}$ & $\begin{array}{c}\% \\
(1) /(2)\end{array}$ \\
\hline Basic or core functions (typical) & 70,267 & 22.9 \\
\hline Collection and monitoring of taxes & 10,952 & 3.6 \\
\hline Public advocacy & 6,233 & 2.0 \\
\hline Diplomacy & 1,831 & 0.6 \\
\hline Police & 18,553 & 6.0 \\
\hline General administration & 31,960 & 10.4 \\
\hline Others & 738 & 0.2 \\
\hline Infrastructure and economic development & 14,678 & 4.8 \\
\hline Statistics & 1,885 & 0.6 \\
\hline Science and technology & 7,331 & 2.4 \\
\hline Agrarian reform and development & 1,943 & 0.6 \\
\hline Transport infrastructure - public contracts and concessions & 1,903 & 0.6 \\
\hline Others & 1,616 & 0.5 \\
\hline Social welfare & 201,318 & 65.6 \\
\hline Public health and sanitary defense & 3,654 & 1.2 \\
\hline Social security and complementary welfare & 36,482 & 11.9 \\
\hline Labor inspection & 232 & 0.1 \\
\hline Fundamental, technical and higher education, funding and educational research & 160,950 & 52.5 \\
\hline Emerging functions & 18,258 & 6.0 \\
\hline Management of public policies & 4,532 & 1.5 \\
\hline
\end{tabular}




$\begin{array}{lcc}\text { State functions / Activity } & \text { Quantity } & \begin{array}{c}\% \\ \text { (1)/(2) }\end{array} \\ \text { Regulation of privatized areas } & 7,686 & 2.5 \\ \text { Infrastructure } & 847 & 0.3 \\ \text { Social policies } & 783 & 0.3 \\ \text { Environment } & 3,138 & 1.0 \\ \text { Culture } & 1,272 & 0.4 \\ \text { Others }{ }^{1} & 2,147 & 0,7 \\ \text { Subtotal } & 304,521 & 99.3 \\ \text { Total - inflow of civil servants - 1995-2014 (2) } & 306,668 & 100 \\ \text { Total - civil servants - } 2014 & 567,157 & 185\end{array}$

Source: Elaborated by the authors based on Boletim Estatístico de Pessoal - Tabela 4.1 - Ingressos no Serviço Público Federal a partir de 1995, Pp. 149-152.

Table 1 shows that a significant renewal of personnel is being carried out through the recruitment of civil servants. The results of the period show the inflow of 306.668 professionals, implying a 54\% renewal percentage of the total 567.157 active civil servants at the federal level (data from 2014).

The greater renewing effort occurred in careers related to the welfare functions, which account for $65 \%$ of the total inflow of personnel. This effort has focused mainly on the replacement and expansion of cadres to universities and technical schools, corresponding to an inflow of 160.950 people. The basic functions of the state received almost $23 \%$ of the total inflow of civil servants, the largest contingent intended to replace personnel in the activities of general administration (31.960 inflows). The activities of police and tax collection were also benefited by a strong inflow of personnel with, respectively, 18.553 and 10.952 new civil servants.

During the period emerging functions received a further 18.258 professionals, who joined mainly activities related to the regulation of privatized areas (7.686) and management of public policies (4.532). Regulatory agencies were created during Fernando Henrique Cardoso governments (1995-2002), mainly in infrastructure and social sectors, which were followed by the expansion of their cadres intensified in the governments of Luis Inácio Lula da Silva (2003-2010) and Dilma Rousseff (2011-2014).

In addition to these activities, sectoral emerging policies such as environment, culture, welfare, and infrastructure were benefited. Finally, the functions related to infrastructure and economic development stand out as the smallest observed renewal: the inflow of 14.678 civil servants throughout the period.

The numbers presented above demonstrate the emphasis on strengthening the state's basic functions, indicating that there is a process of renewal in progress and that the construction of the Brazilian state is still evolving by structuring its basic functions. The numbers also indicate that the recent history is focused on the prioritization of the welfare functions. Hence, it is verified that

${ }^{1}$ Positions and careers not classified in any function. 
expansion is taking place simultaneously throughout all functions, predominantly in welfare and basic or typical functions of the state.

\subsection{Creation and restructuring of careers}

The analysis presented in the following subsections describes how the needs of personnel are met and the impacts on the structuring of state functions at the federal level, considering the recent initiatives of creation and restructuring of positions and careers. The analysis considers aspects of the context and political process behind the organization of personnel in each function.

\subsubsection{Basic functions}

The reinforcement of basic functions of the state is an evident advancement when the creation of positions and careers and the recruitment of civil servants are analyzed. Over the period (1995-2014) there were two movements which emerged. The first one is the completion of an agenda inscribed in constitutional dispositions prescribing the structuring of basic functions of the state. The second is the agenda derived from the reorganization of apparatuses of finance, control, and tax collection.

The first movement indicates that in Brazil, bureaucratic administration is one of the organizational aspects of the state. The draft of the new constitution, approved in 1988, allowed political activism of bureaucratic sectors that were mobilized to approve the strengthening of administrative structures for their areas of activity. The constitution incorporated dispositions that determined the organization of public servants' careers in the areas of public advocacy, police, education, and tax collection. In this manner, the constitutional text brought forth an agenda of bureaucratic construction inspired by a Weberian format and directed to structure the basic functions of the state.

The second movement resulted from the initiative for reform in the area of the treasury, which led to the restructuring of personnel. This was performed in a moment of fiscal adjustment and strengthened the segments of bureaucracy associated with the economic policy. This restructure covered the areas of finance, budget, and control and was accompanied in 1987 by the creation of careers intended for these areas. Thus, the driving forces behind the structuring of the basic functions of the state were the enforcement of 1988 Brazilian Constitution and the political initiatives of reorganization guided by the old bureaucracy.

\subsubsection{Infrastructure and economic development}

The decline of the infrastructure and economic development functions and the presumable deterioration of its capabilities are critical issues in the recent history of the Brazilian state. They have also been weakened by a prolonged disruption in the absence of new institutional design and organization. The decadence of their institutional loci, since the transition to redemocratization, damaged the sectoral policies and their administrative apparatuses. Although the situations vary in each sector, these functions have been dramatically affected by the lack of cadres with appropriate profile and qualification.

In the previous period, these function progressed adopting successful institutional models that shaped the state's activities in the business sector, which were based on the activity of state-owned

JOURnal OF PUblic administration | Rio de Janeiro 53(4):687-710, July - Aug. 2019 
companies with wide autonomy (Martins, 1975). The proliferation and growth of these companies had been occurring since the 1930s, with a peak during the authoritarian modernizing regime, between 1964 and 1985. The crisis of this model left a legacy of fragmentation in the public administration, and the central bodies of coordination and policy formulation weakened in the face of powerful and well-equipped state-owned enterprises.

The recovery of investment is hampered due to lack of personnel, in particular, engineers, many of whom are under-utilized and are performing administrative tasks. These situations are, to a large extent, the result of the dismantling of the structure that was supported by cadres recruited for state-owned enterprises. Previously, staffing followed market parameters and so, cadres from these companies usually took advisory and management positions in the ministries. The crisis of this model has outset a transition process that is still incomplete, with heterogeneous situations among the areas within the function of infrastructure and economic development (Fernandes, Silva, Cunha, \& Alves, 2017).

The new ways in which ministries work in sectoral policies favor the implementation of programs and projects recurring to coordination and articulation mechanisms and decentralization arrangements. This activity, which is already disseminated in sectors such as transport, energy and urban development, is performed by negotiation and management of concession contracts for infrastructure or services provided by public-private partnerships. A second form of action that is being expanded is the transfer of resources to the levels of subnational government (states and municipalities), through terms of adjustment in the form of cooperation agreements. A third way, implemented mainly in the Lula and Rousseff governments, is the direct contracting of engineering projects to recover the country's physical infrastructure, which is undersized and obsolete after a prolonged retraction of investments from 1980 to 1990.

\subsubsection{Social welfare}

The function of welfare strengthened as a concretization of the extension of social rights; which is a distinctive characteristic of the 1988 constitution. This orientation was supported by a continuous expansion of social policies over the governments since the redemocratization, driven by the dynamics of the democratic regime with massive participation of an urban electorate in search of social mobility. The new design of these functions incorporates the federalist orientation of the constitution with impacts mainly on the areas of health and education.

Healthcare is evolving toward interfederative management since the institution of the Unified Health System, incorporated int eh 1988 constitution, but it is still in the process of consolidating its organizational structure. The removal of the federal government from direct operation of health services is one of the most important changes that affects the new organizational design. The deployment of the new model should lead to the transfer of hospitals maintained by the union to the state governments. However, this change faces corporate resistance and implementation risks.

The social welfare went through an organizational transition towards a new design for sectoral policies, based on the action of the ministry in the formulation and control of policies, assigning the operation of services and policy instruments to decentralized bodies (agencies).

The education suffered rearrangements that also arose from federalist guidelines of the constitution, attributing the management of basic and middle-level education to states and municipalities. The

Journal of Public administration ｜ Rio de Janeiro 53(4):687-710, July - Aug. 2019 
federal government remained responsible for its extensive network of institutions of higher and technical education, which had a direct expansion during President Lula's mandate.

The federal government performed in the past by promoting projects for investment in education and following a format based on the execution of projects through centralized management. The new model, which is under construction and was shaped by President Cardoso's government and enforced by the governments Lula and Dilma Roussef, is aimed at decentralization and has evolved to implement the direct transfer of resources and monitoring by performance indicators. Furthermore, the elaboration of methodologies, tools, and mechanisms for policy monitoring and evaluation has mobilized the areas of the function of welfare, and requires adjustment in the profile of the personnel working the agencies responsible for these policies. These policies emphasize the establishment of goals and the observation of results by using indicators. In this sense, one important advance has been the application of the national examinations applied to students throughout the education system.

\subsubsection{Emerging Functions}

The definition of emerging functions takes into consideration the history of the construction of the Brazilian state, and the trends that are shaping the contemporary states. These are functions that comply with some of the recent initiatives to create and restructure positions and careers. The change in the profile of public administration to an articulate and decentralized action, the strengthening of central administration, which is responsible for formulating and monitoring public policies and the creation of regulatory agencies, and the restructuring of personnel cadres are shaping the agenda that is currently being implemented.

There are advances through the incorporation of innovations in careers that were created or restructured to work in the management of public policies, regulation, specialized technical support, and information technology.

The selection and training of managers is crucial in order to make viable strategies for the reform and modernization of public administration, and this issue was explored with the creation of the career of Specialist in Public Policy and Governmental Management in 1989. This career is characterized by its generalist profile and the operation in transversal issues, in all agencies of the federal administration. Its profile makes this career a model close to the requirements that could be associated with the emerging role of coordination and articulation of governance arrangements in the public sector.

The consolidation of the Governmental Management career is also supported by the allocation of these professionals together with personnel from other careers in order to create the management cycle of public policies. The conception of the management cycle presupposes interrelated processes that encompass the activities of formulation and implementation of public policies that are distributed throughout the organs of federal administration. The public policies are seen in the perspective of their management as functions, processes, and norms related to the aspects of organization, planning, budget, finance and control.

As an initiative of expansion of the state apparatus that externalizes some of its emerging functions, the regulation of markets, in connection with the privatization of state enterprises, has advanced since the 1990s. This is an agenda that was associated with the reforms of privatization, which comprised a blueprint for the fiscal adjustment in a context of economic crisis with persistent inflation and fiscal crisis of the state. The emergence of the regulatory state corresponds to a vision of the restructuring

Journal of Public administration ｜ Rio de Janeiro 53(4):687-710, July - Aug. 2019 
of the state that proposes its withdrawal from direct action in the production of goods and services, in the scope of the infrastructure and economic development functions, to focus on the articulating and "facilitating" action.

The careers related to the work of regulatory agencies were created in successive waves: between 1995 and 1998, during President Cardoso's first mandate, the agencies of infrastructure in productive sectors that have become controlled privately or through mixed control between the state and the market: energy, telecommunications, and petroleum. In the subsequent period, in President Cardoso's second mandate, there was expansion and diversification of markets in the area of health, with the creation of regulatory agencies of sanitary surveillance and supplementary health. A third wave has appeared since 2001, facing the pre-existing markets that were to be the object of regulatory laws: land transport, waterway transport, cinema and audiovisual, civil aviation and mining.

In the sectors of energy and communications there was an in-depth transformation, with the extinction of departments and privatization of state-owned enterprises (Fernandes, 2015; Quintella \& Costa, 2009), leading to reducing and relocation of personnel in private markets or regulatory agencies $^{2}$. During the 1990s and the beginning of the 2000s, ten regulatory agencies were created in Brazil to regulate economic areas previously privatized (Cunha, 2017; Fernandes et al., 2017)3.

Concerning the functions of social welfare, striking innovations were the conditional cash transfer programs that were developed at the same time in which the organizational structures were built and that were finally supported by the Ministry of Social Development, which was created in 2004. Their characteristics of inter-sectoriality and transversality, involving different sectors and levels of government, made these programs a true storefront for innovative products in public policy. In the infrastructure function, the advances on the organizational restructuring of ministries and secretariats that operate in these sectoral policies are still limited, despite the creation of regulatory agencies and legal frameworks for privatized sectors.

During the mandates of Presidents Lula and Rousseff, two careers were created to populate and professionalize social and infrastructure ministries: The Technical Analyst of Social Policies (2009) and the Infrastructure Analyst (2007). The job positions in these two careers are to be fulfilled through competitive examination. A third career of Information Technology Analysts was created in 2009, focused on improving the federal government's digital governance.

The careers and the newly created positions to work in the areas of social policy, infrastructure and information technology met the need to internalize specialized technical knowledge, by the recruitment of specific professional profiles, for example engineers, economists, and statisticians. These initiatives are aimed at meeting the needs of restructured areas such as social policy as well as situations with urgent demand for personnel, such as in the area of infrastructure to attend a new model of federal government role implemented by the governments of Presidents Lula and Rousseff, organized through the Acceleration Growth Program ${ }^{4}$.

\footnotetext{
${ }^{2}$ Baer and McDonald (1997) describe the privatization of an electric company in the state of Rio de Janeiro. According to the authors, one of the main measures of new owners was to improve efficiency and reduce bureaucracy.

${ }^{3}$ The eleventh regulatory agency was created in 2017, transforming the National Department of Mining Production in the National Agency of Mining.

${ }^{4}$ The Acceleration Growth Program (Programa de Aceleração do Crescimento - PAC) was a strategy for infrastructure improvement led by the Presidency in order to enhance economic growth and reorganize public investments in Brazil. For detailed analyses of the public bureaucracy in the area of infrastructure in Brazil, see Paula, Palotti, Cavalcante, and Alves (2017).
} 
The redesign of the positions and careers in emerging functions has incorporated innovations such as generalist competencies, rules of development coupled with in-service training and performance evaluation and reward systems.

\section{METHODOLOGY}

The methodology for empirical analysis used ANOVA statistics and compared a set of means from different groups of people (Field, 2009). The data was collected for a previous work Middlelevel Bureaucracy Research, led by Enap in 2014, focused on civil servants who were occupying appointed managerial positions in the federal executive branch. For this research, the managers were distinguished according to their careers and respective state functions, as described in the previous section. In total, 4.782 respondents were analyzed in the survey. It corresponds to $18,88 \%$ of the middle-level management population ${ }^{5}$. This article has benefited from the efforts of Cavalcante, Camões, and Knop (2015), who originally carried out similar research to understand differences and similarities between the bureaucrats of different sectors of the government.

\section{SIMILARITIES AND DIFFERENCES ACCORDING TO STATE FUNCTIONS}

This section will describe characteristics of the managers of the Brazilian federal bureaucracy, contrasting with different careers of the federal government and analyze their connection to the four state functions. The following dimensions will be discussed: sociodemographic characteristics (gender, age and education), professional attributes (time in the appointed position and time of professional experience), performance (degree of autonomy, degree of influence, commonly developed activities and interaction with partners and other government actors) and perception about how directors and advisors are chosen in their organizations.

The first difference to note is the participation of women in the workforce. As expected on the grounds of previous surveys (Enap, 2014), less women hold positions in the middle-level bureaucracy $(33,8 \%)$ than the total of women observed in the civil service as a whole (46\%). In part, this is because women occupy fewer command posts than men (Firmino \& Silva, 2015).

The analysis focusing on state functions (Graph 1) shows a significant difference of average percentage in comparison to the four categories $(F(1,4780)=4.410, p<.05)$, demonstrating different forms of recruitment for career and appointed positions. Two patterns can be observed in the groups. Firstly, the core and emerging functions are not statistically different (Mean difference (I-J) $=-0.016$, $p>.05$, two-tailed). Secondly, social welfare and infrastructure and economic development functions are statistically similar (Mean difference $(\mathrm{I}-\mathrm{J})=-0.038, p>.05$, two-tailed).

The highest value for the welfare function (42\%) stands out for the composition of careers in this sector, mostly made up of professions related to education, health, and social assistance, with greater participation of women.

\footnotetext{
${ }^{5}$ The complete survey encompassed 7,223 respondents (28.51\% of the population). This article only considered respondents in careers in the federal government, excluding retired civil servants and those working in states and municipalities, political appointees as well as respondents in non-identified careers.
} 
GRAPH 1 WOMEN PARTICIPATION BY STATE FUNCTIONS (\%)

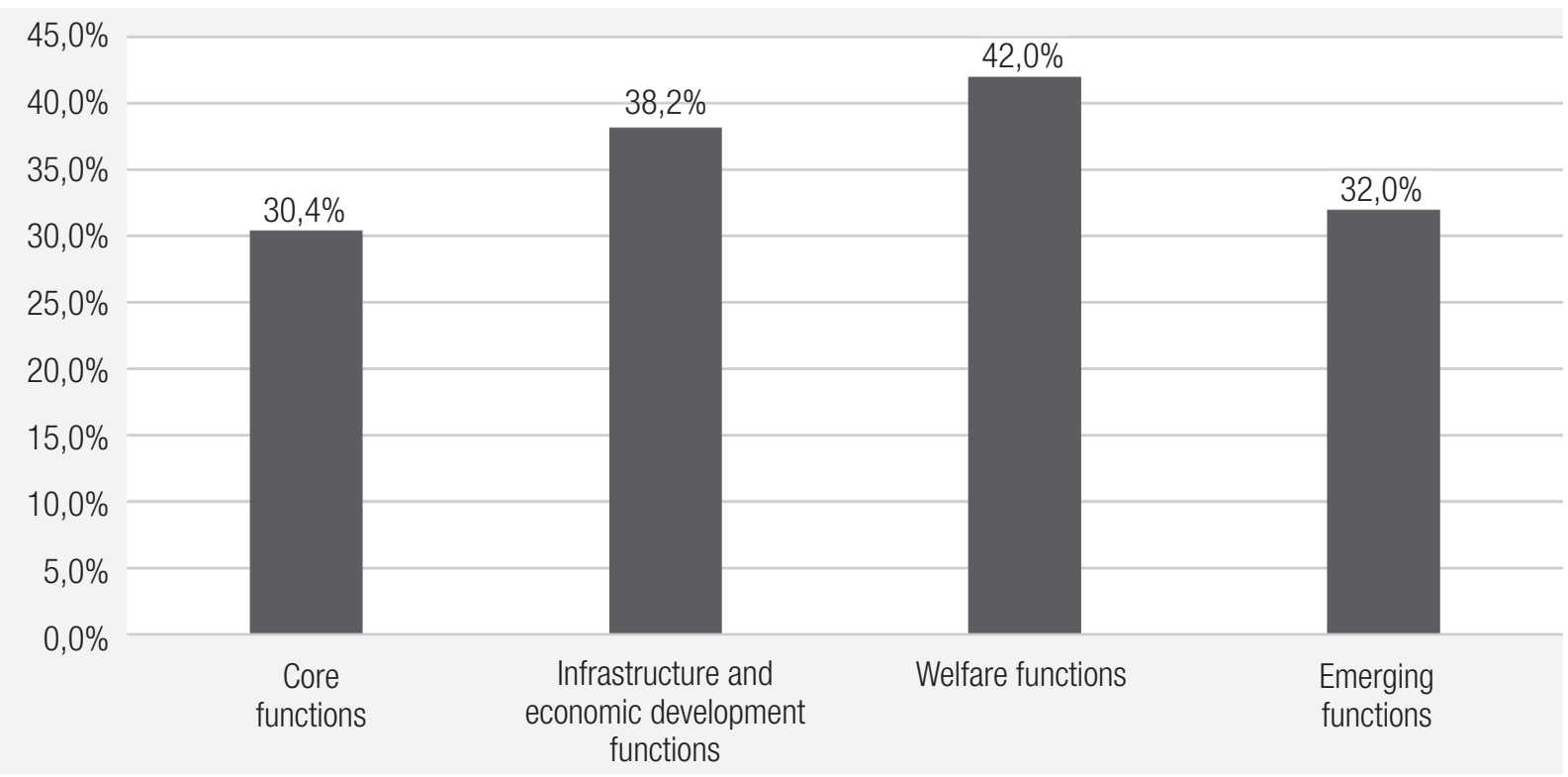

Source: Elaborated by the authors based on Enap's database on middle-level bureaucracy survey.

An interesting indicator to understand the public administration in Brazil is the mean age of the workforce, a dimension affected both by recent recruitment processes for the careers analyzed, and by the standards adopted to recruit personnel to managerial positions (directors and advisors).

The mean age of the four groups shows remarkable differences $(F(3,4778)=72.442, p<.05)$. The youngest group belongs to emerging functions while the oldest group relates to infrastructure and economic development functions. In percentage terms, managers from emerging careers have the highest percentage of respondents up to 40 years $(51,3 \%)$, while the smallest contingent of respondents are over 60 years $(2,8 \%)$, pointing out the existence of a set of younger civil servants (see table 2 and graphic 2).

\section{TABLE 2 AVERAGE AGE BY STATE FUNCTIONS}

\begin{tabular}{lccc|}
\hline State functions & Respondents & Mean & Standard deviation \\
\hline Basic or core functions & 1,963 & 44.8299 & 9.86921 \\
\hline Infrastructure and economic development functions & 401 & 48.0224 & 9.45288 \\
Welfare functions & 939 & 46.7891 & 10.19094 \\
Emerging functions & 1,479 & 41.8587 & 9.17546 \\
Total & 4,782 & 44.5634 & 9.90543
\end{tabular}

Source: Elaborated by the authors based on Enap's database on middle-level bureaucracy survey. 


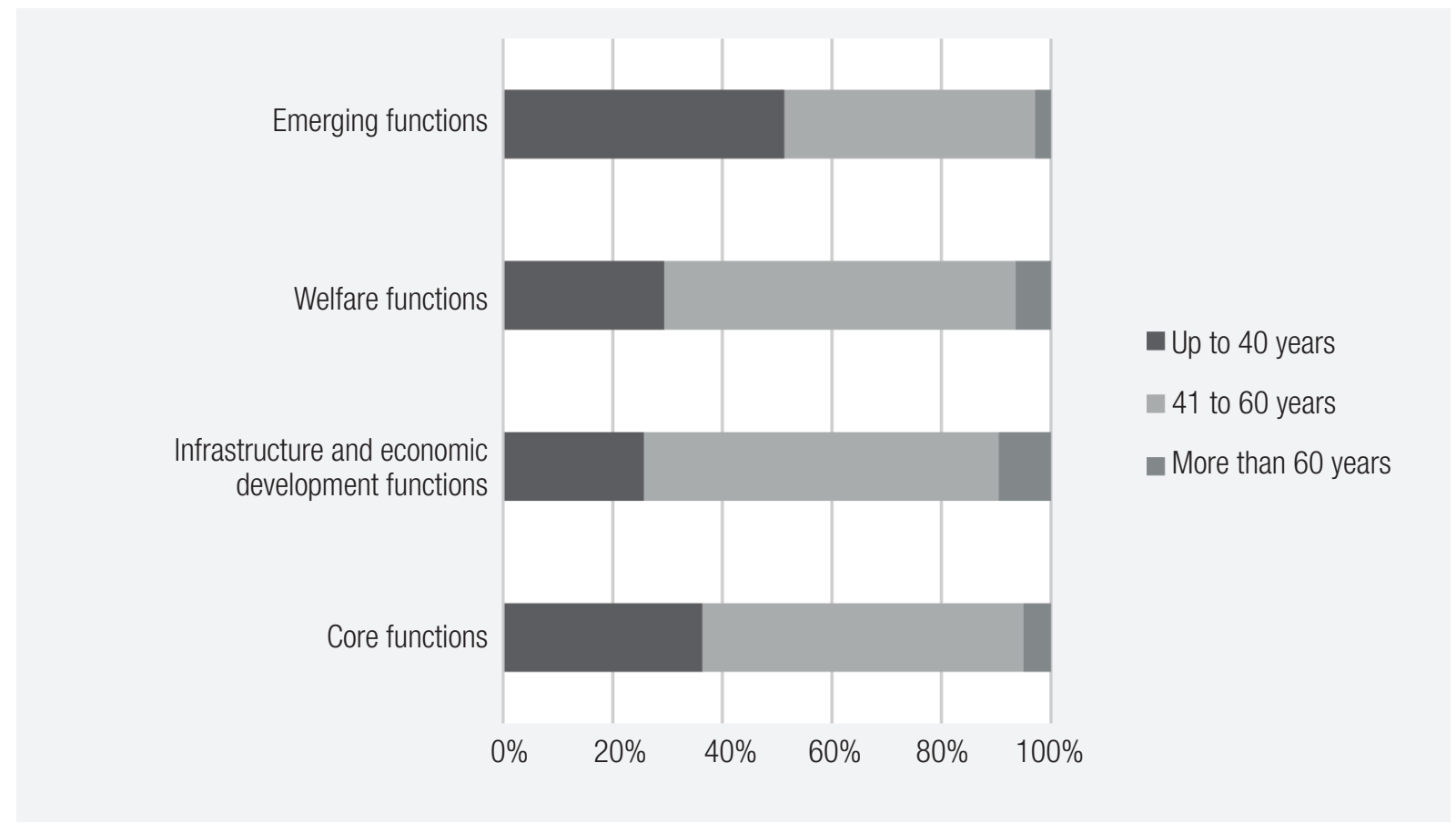

Source: Elaborated by the authors based on Enap's database on middle-level bureaucracy survey.

Analyzing the groups together, all the means are statistically different, except for infrastructure and economic development and for welfare functions (Mean difference $(\mathrm{I}-\mathrm{J})=-1.233, p>.05$, twotailed). Both correspond to the oldest extracts.

Education is another relevant sociodemographic indicator. The comparison shows that the majority of managers has a degree. This high education level stems from the open, competitive, and public exams, which was adopted in a strict way by the 1988 Brazilian Federal Constitution.

There were statistically significant differences between managers in the four state functions $(F(3$, $4778)=36.746, p<.05)$. When compared, the emerging functions group had the highest percentage of graduated managers (77,3\%), a distinct percentage from all other groups (see Graph 3 ). The second highest $(70,6 \%)$ was infrastructure and economic development careers (Mean difference $(\mathrm{IJ})=.068$, $p<.05$, two-tailed).

In sum, the group of managers of emerging functions careers has the highest education level, even when compared to the group that traditionally shows a professionalized bureaucracy linked to economic development. It is worth noting, however, that all groups have a higher education when compared to other civil servants, to the private sector or the whole Brazilian population.

As noted earlier, all respondents are appointed managers in the middle-level bureaucracy of federal government. They correspond to the strata responsible for directing work teams or advising authorities. There are some differences concerning the length of time occupying the position, which usually reflects the turnover. 
GRAPH 3 GRADUATED PERSONNEL BY STATE FUNCTIONS (\%)

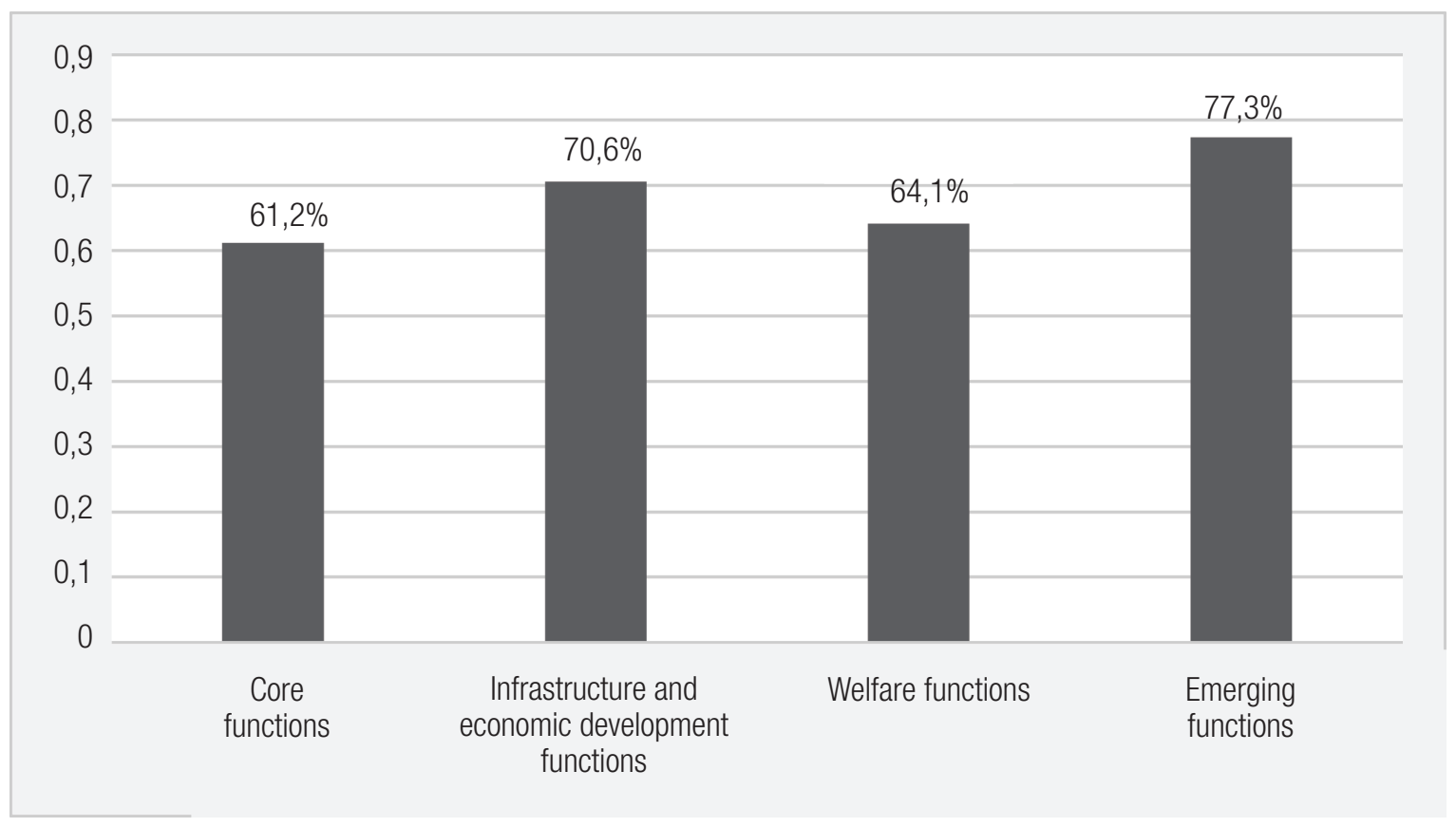

Source: Elaborated by the authors based on Enap's database on middle-level bureaucracy survey.

As shown in Graph 4, there is a statistically significant difference in the average time managers occupy appointed positions when comparing the four state functions $(F(3,4840)=33.05, p<.05)$. Analyzing the groups individually, there is a seemingly similar set formed by managers whose careers belong to the basic functions of infrastructure and economic development, and welfare, as opposed to the emerging group. For the former group of functions, the average time in the position is four years, the time of a presidential term in Brazil. For the latter, the average time is almost half, indicating more dynamicity and less stability.

Regarding work experience, questions were asked to understand the managers' professional life whether in public, private, or nonprofit sectors. Initially, very similar standards were observed for all managers in the four functions. The highest average of years of experience was in the federal public sector, followed by the private sector, the state level, and, much less time in non-governmental organizations and municipalities.

In all these different segments, the experience among the groups are statistically different from one another, as shown by $F$ statistics in all columns of Table 3 and illustrated in Graph 5, except the number of years working in the state level, where the values are statistically equal. The two most recurring previous experiences are in the federal government and the private sector. For the first, the infrastructure and economic development and welfare functions have the highest average time of previous work experience and they are statistically equal (Mean difference $(\mathrm{IJ})=-.67, \mathrm{p}>.05$, two-tailed). The emerging functions group has the lowest average experience in the federal public sector and are among those with greater experience in the private sector, together with the infrastructure and economic development group, with no statistically significant difference (Mean difference $(\mathrm{IJ})=.16, \mathrm{p}>.05$, two-tailed). 


\section{GRAPH 4 AVERAGE TIME IN THE CURRENT COMMISSIONED POSITION BY STATE FUNCTIONS (NUMBER OF YEARS)}

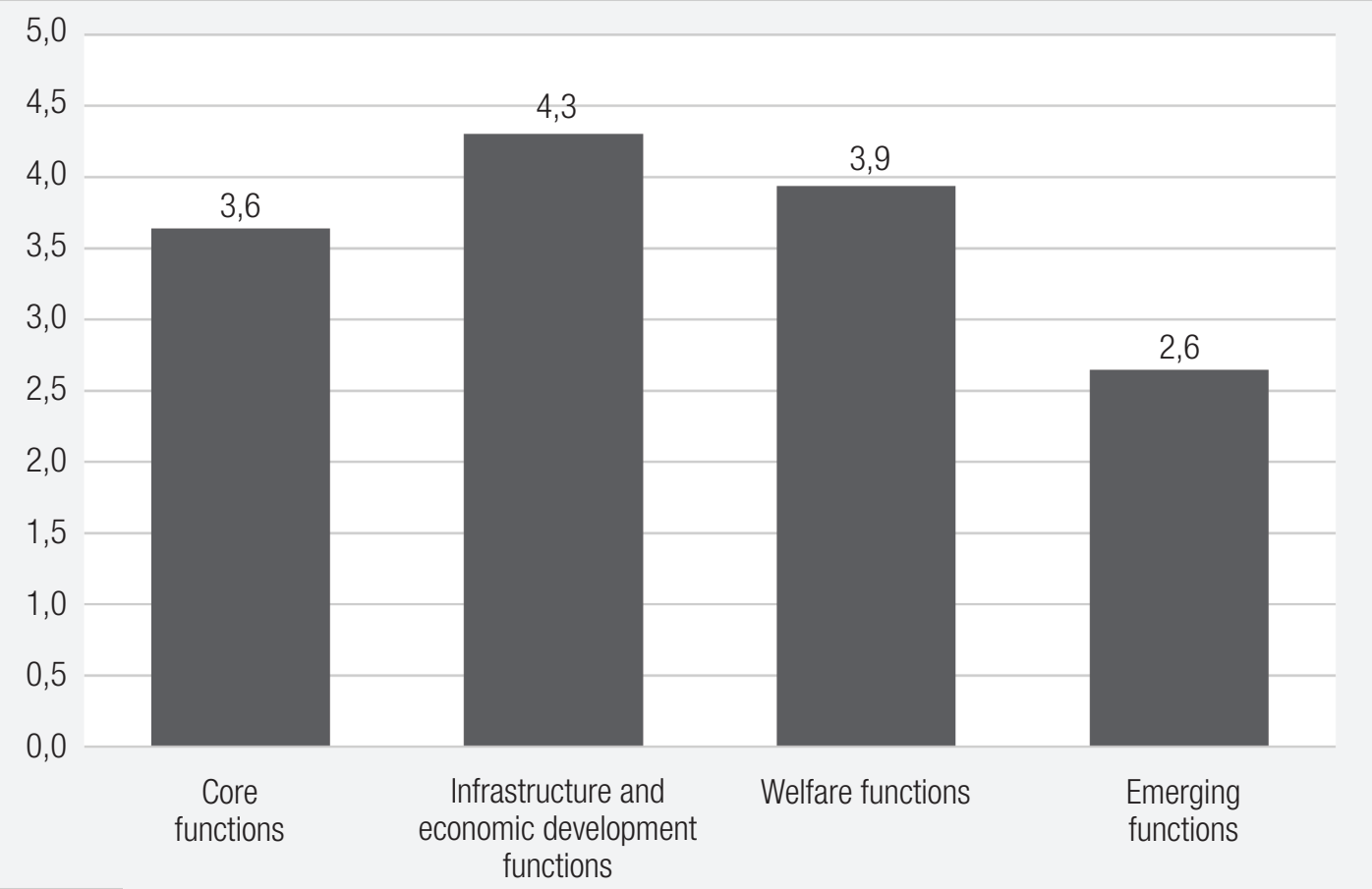

Source: Elaborated by the authors based on Enap's database on middle-level bureaucracy survey.

TABLE 3 AVERAGE TIME OF PREVIOUS WORK EXPERIENCE BY STATE FUNCTIONS (YEARS)

\begin{tabular}{|c|c|c|c|c|c|}
\hline State functions & $\begin{array}{c}\text { Federal } \\
\text { government } \\
F(3.4840)= \\
81.68, p<.05\end{array}$ & $\begin{array}{c}\text { States } \\
F(3.4838)= \\
0.37, p>.05\end{array}$ & $\begin{array}{c}\text { Municipalities } \\
\mathrm{F}(3.4838)=7.18 \\
p<.05\end{array}$ & $\begin{array}{l}\text { Private sector } \\
F(3.4839)= \\
6.71, p>.05\end{array}$ & $\begin{array}{c}\text { Non-governmental } \\
\text { organizations } \\
\mathrm{F}(3.4838)=7.21, \\
p<.05\end{array}$ \\
\hline Core functions & 15.93 & 1.04 & 0.24 & 3.67 & 0.25 \\
\hline $\begin{array}{l}\text { Infrastructure and } \\
\text { economic development } \\
\text { functions }\end{array}$ & 18.44 & 0.94 & 0.65 & 4.07 & 0.52 \\
\hline Welfare functions & 17.77 & 0.94 & 0.42 & 3.29 & 0.55 \\
\hline Emerging functions & 11.96 & 0.94 & 0.35 & 4.23 & 0.43 \\
\hline Total & 15.28 & 0.98 & 0.35 & 3.80 & 0.39 \\
\hline
\end{tabular}

Source: Elaborated by the authors based on Enap's database on middle-level bureaucracy survey. 


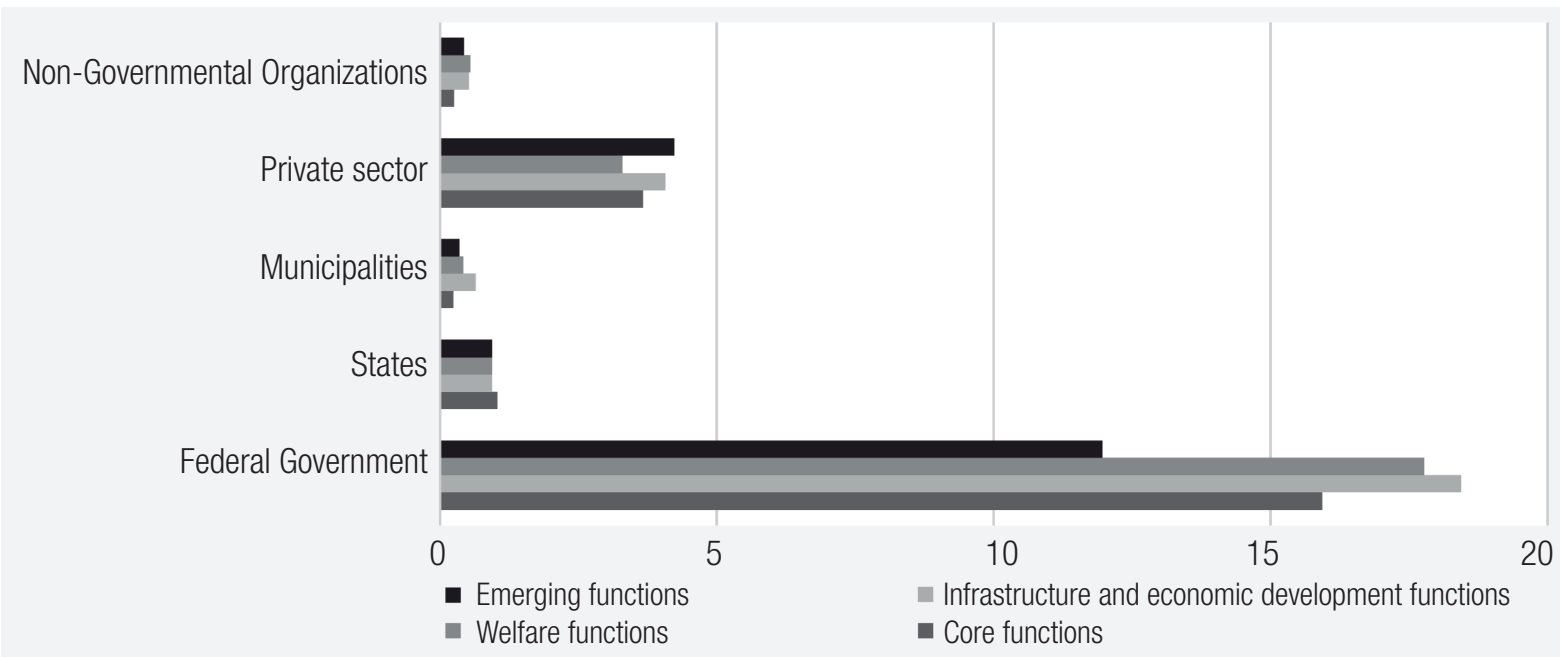

Source: Elaborated by the authors based on Enap's database on middle-level bureaucracy survey.

An important element for understanding the current activities of those responsible for middle management is the autonomy to set objectives and targets in the workplace, to manage people (to decide on how to organize the team) and to define the most appropriate techniques and methods to carry out the work. On average, respondents have a relatively high degree of perceived autonomy with a mean score higher than 3.5 , on a scale of 1 to 5 , where 1 is the lowest degree of autonomy and 5 the highest.

In Graph 6, it is not possible to observe a statistically significant difference among the state functions groups for the degree of autonomy to manage people $(F(3,3829)=1.79, p>.05)$ and the definition of techniques and methods $(F(3,3865)=.91, p>.05)$. There were only significant distinctions regarding the decision of setting goals and objectives in the workplace $(F(3,3669)=11.12, p<.05)$.

\section{GRAPH 6 'PERCEPTIONS OF AUTONOMY BY STATE FUNCTIONS (0-5 SCALE)}

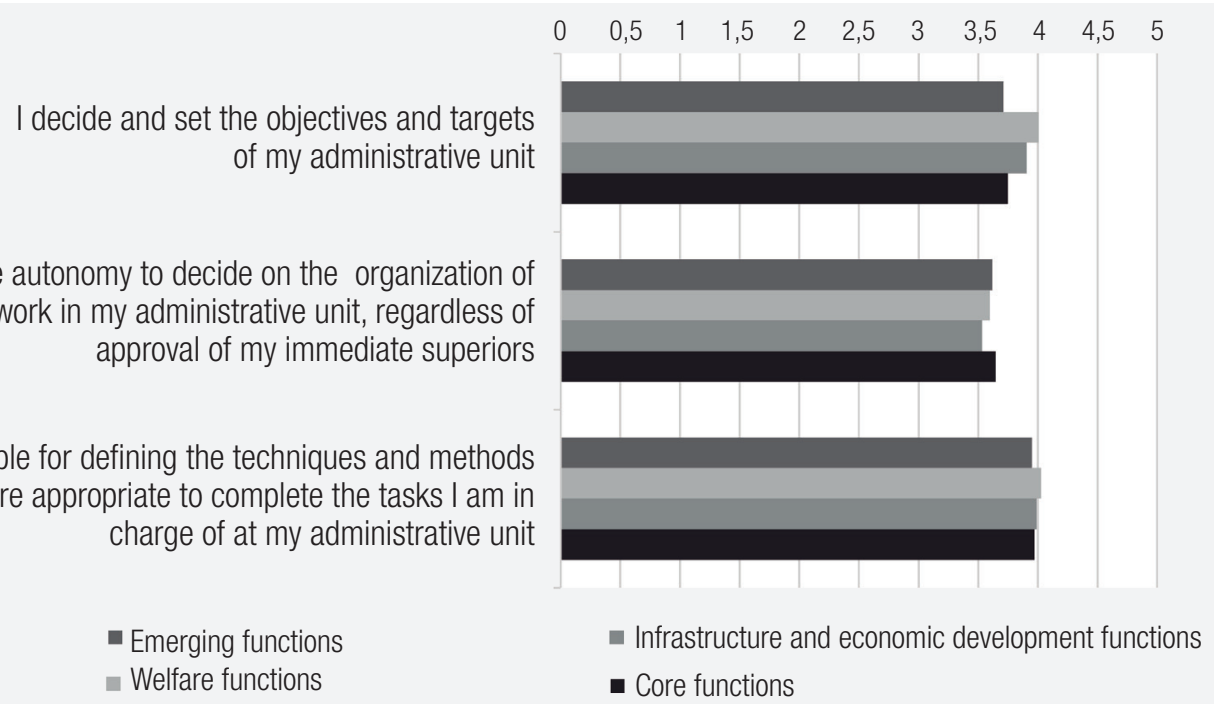

I have the autonomy to decide on the organization of my team's work in my administrative unit, regardless of approval of my immediate superiors

I am responsible for defining the techniques and methods I consider more appropriate to complete the tasks I am in charge of at my administrative unit

$$
\text { - Welfare functions }
$$

- Core functions

Source: Elaborated by the authors based on Enap's database on middle-level bureaucracy survey. 
Two distinct groups emerged. The first group is formed by the managers of the careers of emerging and core functions (Mean difference $(\mathrm{I}-\mathrm{J})=-.029, \mathrm{p}>.05$, two-tailed); the second group is formed by the careers of infrastructure and economic development and welfare (Mean difference $(\mathrm{I}-\mathrm{J})=.098$, $\mathrm{p}>.05$, two-tailed). The latter group has greater perceived autonomy than the first, at least about setting goals and objectives. Despite this distinction, it is interesting to note that for the other two dimensions of autonomy the groups did not differ, which may indicate a more organizational element than their careers to interfere in this perception of autonomy. This hypothesis is supported by the findings of Cavalcante, Camões, and Knop (2015). According to their study, there were noticeable distinctions between different public policy sectors for the same dimensions.

Another important dimension to understand is that the role of these managers refers to the degree of perceived influence on decision-making. In Graph 7, the first aspect concerns the opportunity to participate in meetings with top managers of the organization. There is a statistically significant difference among the state functions groups $(F(3,4747)=16.05, p<.05)$, especially the perception of a minor role for managers in the core functions careers when compared to the others.

\section{GRAPH 7 PERCEPTIONS OF INFLUENCE IN DECISION-MAKING BY STATE FUNCTIONS (0-5 SCALE)}

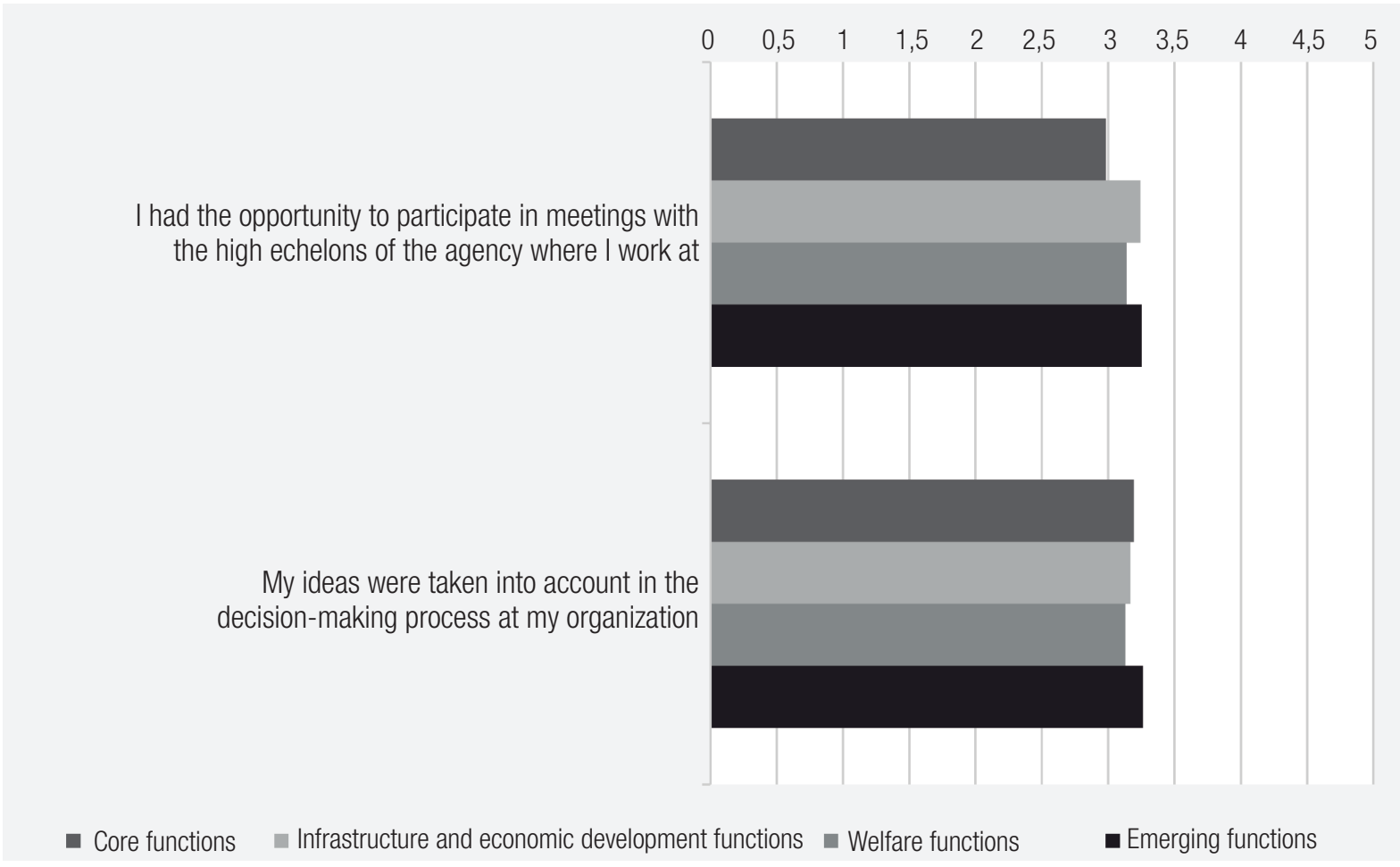

Source: Elaborated by the authors based on Enap's database on middle-level bureaucracy survey.

Concerning the second aspect shown in the Graph 7 - when asked about the influence of their ideas in the decision-making process - the evaluations of managers in all functions were virtually at the same level. The only distinction was between managers in emerging functions compared with 
managers in welfare functions, the perception of the latter that they were less involved in the decisionmaking process than the former $(F(3,4669)=3.66, p<.05)$.

The influence in decision-making processes is less prominent than the degree of autonomy, although the values are not low for the influence dimension. On a scale of 1 to 5 , where 1 is the lowest degree of influence and 5 the highest, the average value was close to 3 . There are more differences in this dimension among the groups of careers than in the dimension of autonomy.

The analysis of the managers' daily routine in the Brazilian public service refers to the activities they perform. There is a predominance of individual dialogues and meetings with internal stakeholders and the elaboration or validation of internal documents. Next, the most common are the activities related to the production of studies and research, feeding or validation of information systems and participating in meetings with external interlocutors. Finally, there is the validation of normative and external documents, business trips and participation in events.

In Graph 8, the managers of the emerging functions group stand out as the most frequent in attending meetings with external parties and in the preparation of internal documents. It appears that the profile of this group is characterized by the importance they attribute to the interrelation with other bureaucrats and to the preparation of reports and technical notes to support the decisionmaking process. Managers of the welfare area differ from others by participating in more frequent activities such as business trips and the organization and participation in conferences and events. Thus, these bureaucrats are characterized by their broad coordinating initiatives with stakeholders, who are compatible with the organization of health services, social assistance, and education, as public policies are now decentralized to state and municipalities in Brazil. Managers of basic and infrastructure functions are not notorious for a particular activity.

\section{GRAPH 8 MAIN ACTIVITIES UNDERTAKEN BY STATE FUNCTIONS (0-5 SCALE)}

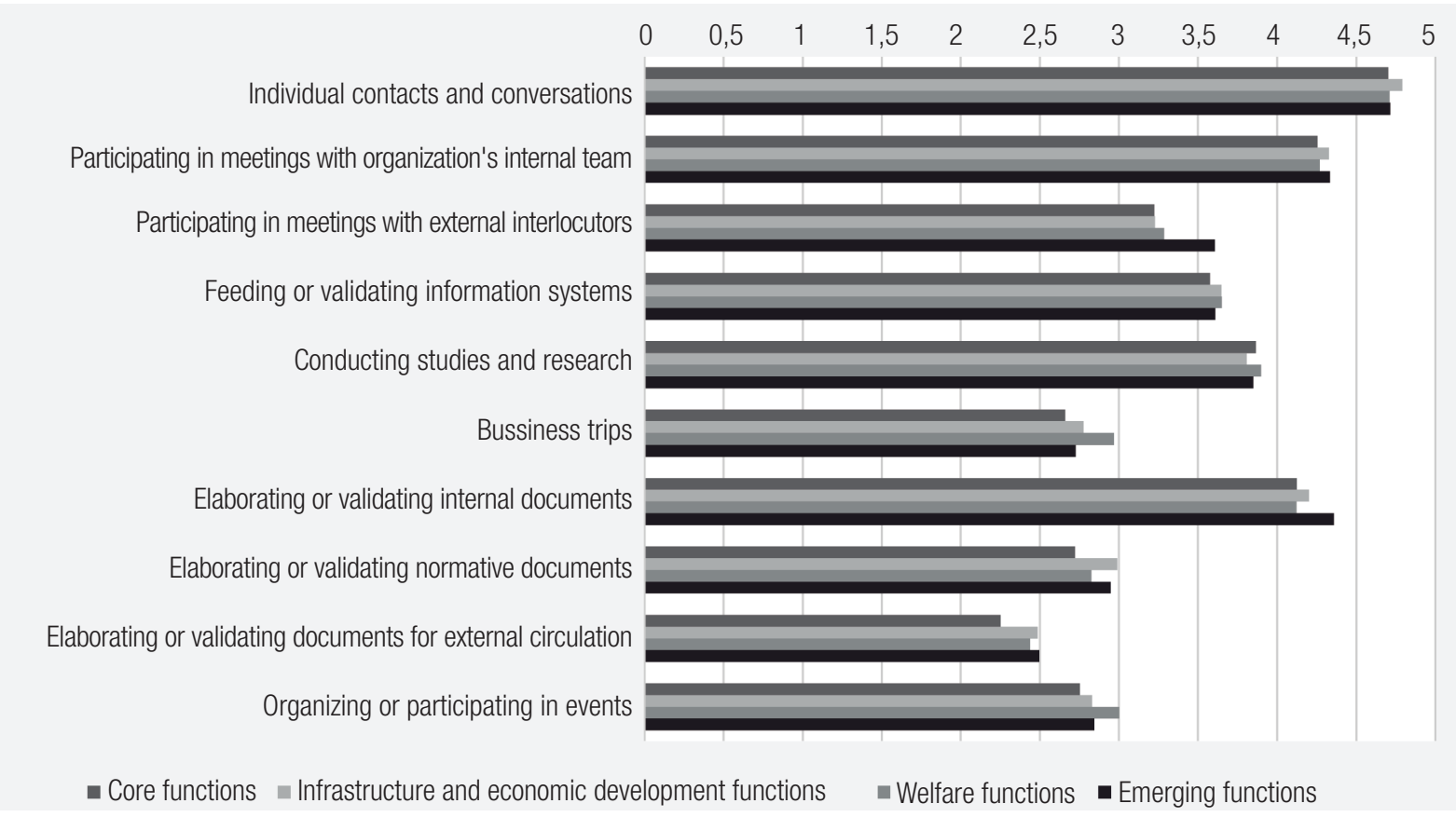

Source: Elaborated by the authors based on Enap's database on middle-level bureaucracy survey. 
The type of interaction established by the bureaucracy involving various stakeholders is an important factor to understand the insertion of these managers and relational aspects. Differences among the careers are expected according to the type of interaction most typically exercised in each function. These differences mean particular models of interaction within the government and between state and society.

Thus, in Graph 9, respondents, in general, have the highest level of interaction with internal elements of the organization, such as subordinates, superiors, and colleagues. According to the state function, however, there are significant differences regarding their interaction. For respondents from careers associated with emerging functions, there is interaction with other government agencies and the Civil Office. They stand out for intragovernmental dialogue. For the welfare function, there is a predominance of dialogue involving these managers more directly with civil society and citizens, more often than in other careers, which is understandable due to the proximity of this bureaucracy to direct provision of public services.

\section{GRAPH 9 INTERACTIONS BY STATE FUNCTIONS (0-5 SCALE)}

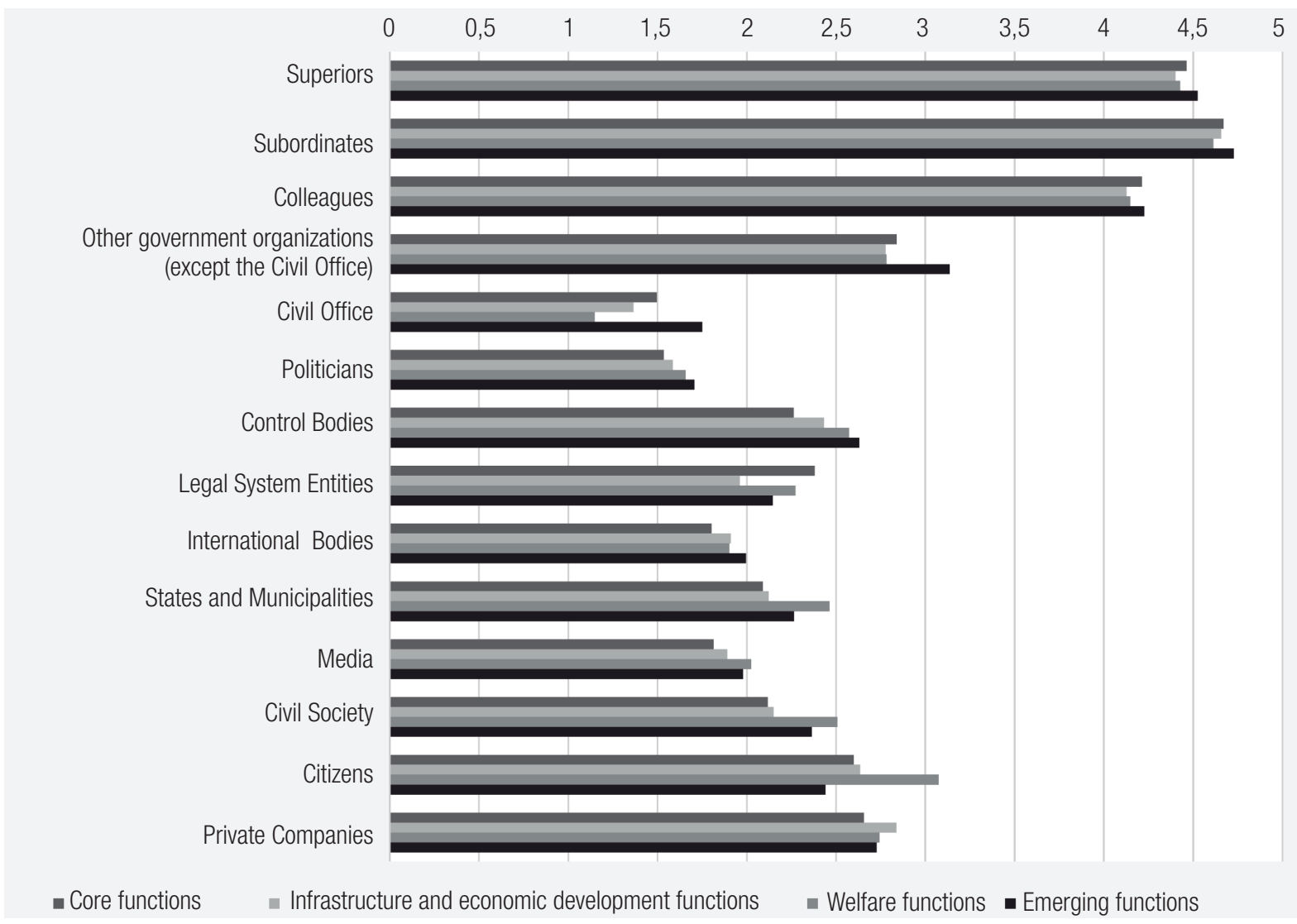

Source: Elaborated by the authors based on Enap's database on middle-level bureaucracy survey.

Regarding the infrastructure and economic development function, despite its major role in dialogue with companies, the difference observed is not statistically significant when compared to other careers. 
For the careers of the core functions, along with the careers related to the welfare function, there is more interaction with the legal system entities, which is understandable because they are dedicated to providing activities of public security and legal representation of executive power.

The survey also inquired about the perception of Brazilian managers on the criteria they consider to be most important to occupy an appointed position in the agencies where they work. In general, it is observed that the three most important factors to be appointed are bonds of trust, expertise, and experience. The network of relationships and political party affinity follow these three factors (see Graph 10).

\section{GRAPH 10 FACTORS INFLUENCING THE APPOINTMENT BY STATE FUNCTIONS (0-5 SCALE)}

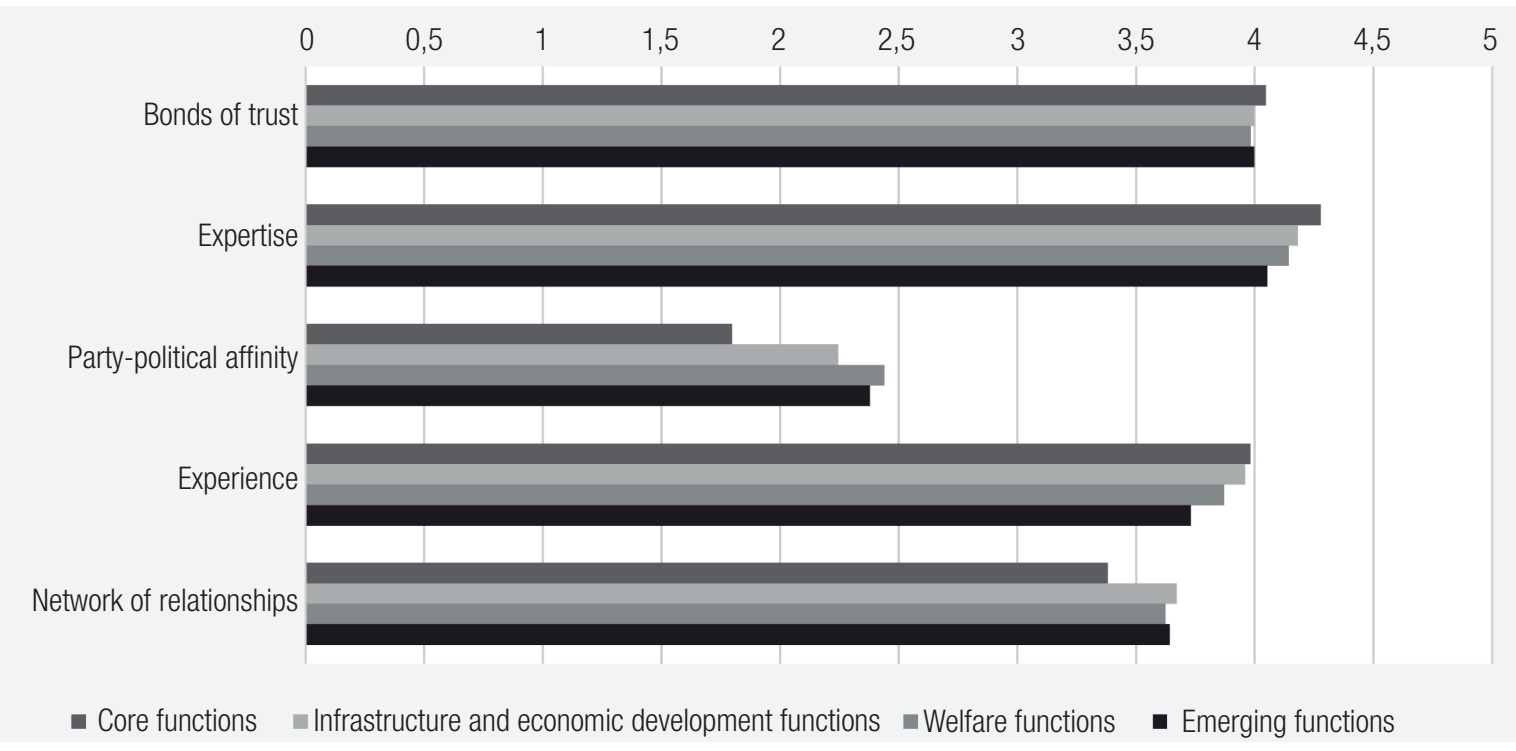

Source: Elaborated by the authors based on Enap's database on middle-level bureaucracy survey.

All groups see bonds of trust as important. There is no statistically significant difference among the groups $(F(3,4839)=1.29, p>.05)$. The managers of the core functions careers emphasize the importance of expertise to be appointed but rate political party affinity and affiliation to a network of relationships with the lowest value of importance. This finding is more adherent with a central area of activity of the state, in general with the most consolidated careers, structured in a pyramidal shape hierarchy, and organized in areas such as tax collection, public advocacy, public security, and diplomacy. 


\section{DISCUSSION AND CONCLUSIONS}

This article was based on a survey focused on the middle-level bureaucrats who occupy appointed managerial positions. The database was observed using the logic of the four state functions theoretically defined: basics; infrastructure and economic development; social welfare and emerging.

In general, the data evidence a highly-professional bureaucracy in Brazil. Managers in the federal government have a high degree of education and previous experience working in the federal government or private sector. They also perceive themselves as having a high level of autonomy but only average influence in decision-making. Additionally, they regard technical factors related to expertise, experience and relational aspects such as networking and trust as the most prevalent influences in the nomination process for commissioned management positions in their organizations.

Some interesting differences arise regarding the four state functions. About the emerging functions, there are some aspects that can be highlighted concerning the bureaucrats working in appointed middle-level management positions in these areas. Firstly, they are relatively young; they have the highest level of education; they work in managerial positions for a shorter period in contrast to their counterparts (those who work within the other functions) and stand out for the importance they give to intra-governmental dialogue. This study corroborates the existence of a new profile of managers recruited from careers that have characteristics of generalist competencies, soft hierarchy and formal structures, and easy mobility through different bodies of the public administration when compared with the traditional models of public sector careers.

The majority of respondents who work in positions that carry out welfare functions are women. These positions encompass policy areas such as education, health, and social assistance. Although they do not have vast previous experience working in the subnational level, these bureaucrats have to develop strong connections with states and municipalities, as well as with citizens. Those who occupy the positions in the areas of infrastructure and economic development have significantly more experience in the private sector when compared to the managers that carry out emerging functions. They also have remarkable interaction with private companies in their professional area.

Although the perception of autonomy is high among the managers in the four functions, there is a distinction about the autonomy they have to define objectives and goals in the workplace. In this respect, the managers who carry out infrastructure and economic development functions, as well as the managers who implement welfare functions deemed to have greater autonomy than the other managers. This evidence may indicate that managerial activity is influenced by structures that have a stricter vertical hierarchy and that have more clearly defined and formalized tasks.

The development of these two functions of the state was supported in the past by career structures that were created in an environment of decentralization and institutional autonomy. These careers were structured in large agencies or state companies and were organized as services that aimed at providing an insulated style of action and devoting less attention to external connections. These considerations are assumptions to be investigated in future research.

The core functions managers see themselves as having less autonomy and influence in the decisionmaking process when compared to other managers. The managers appear to be competent technicians for traditional state activities. In this area, bureaucratic structuring has progressed significantly and is corroborated by the evidence of a managerial profile that is more hierarchical and less oriented 
to external action. What is expected for this function is the consolidation of organizational models inspired by the "traditional" Weberian style.

This article is an exploratory research contributing to the comprehension of a new theme in Brazil that needs further study and can be applied to other contexts and countries. New areas of research can investigate how public bureaucrats are allocated and how their capacities are developed to improve state functions. The approach proposed by this article can be complemented by researching how organizations prioritize administrative tasks among their personnel and how politicians interfere in the process of recruitment and career development of managers in the public sector.

In the perspective of human resources management, a new path of research can be highlighted. Besides considering the necessity of recruiting bureaucrats to substitute retired people or to implement new areas of state activity, it is crucial to consider the profile of those being hired in the bureaucracy and for what purpose. The profile of the personnel will depend on factors such as how the competitive examinations are designed and the average type of education the applicants have. On the other hand, the purpose for which people are recruited needs to be questioned. Some activities simply become obsolete or are outsourced, while new emergent tasks can be essential for an ever-changing concept of citizenship.

In this sense, given the differences identified among careers in the federal government, what are the implications these characteristics have for attempts of reorganization and rationalization of human resources in the public sector? Personnel expenditures are always a concern for budget adjustments. Considering the differences in careers could be a guideline for implementing changes and balancing profiles when recruiting and training civil servants.

Finally, this study presents and tests an empirical-based classification for careers that should be useful for other researches dedicated to the public sector in Brazil, at the federal or subnational level. It would be interesting to apply this classification to other countries in order to compare different state-building strategies and their recent tendencies. 


\section{REFERENCES}

Baer, W., \& Mcdonald, C. (1997). Um retorno ao passado? A privatização de empresas de serviços públicos no Brasil: o caso do setor de energia elétrica. Planejamento e Políticas Públicas, 16, 5-38.

Barberia, L., \& Praça, S. (2014). Who gets political appointments? Party loyalty and bureaucratic expertise in Brazil. In Annals of the Midwestern Political Science Association Meeting. Chicago, IL.

Bresser-Pereira, L. C. (1998). Reforma do Estado para a cidadania: a reforma gerencial brasileira na perspectiva internacional. São Paulo, SP: Ed. 34.

Bresser-Pereira, L. C. (2004). Democracy and public management reform: building the republican State. Oxford, England: Oxford University Press.

Cavalcante P., Camões, M. R. S., \& Knop, M. N. H. (2015). Burocracia de médio escalão nos setores governamentais: semelhanças e diferenças. In P. Cavalcante, \& G. Lotta (Org.), Burocracia de médio escalão: perfil, trajetória e atuação (pp. 57-90). Brasília, DF: Escola Nacional de Administração Pública.

Cavalcante, P., \& Carvalho, P. S. (2017). Profissionalização da burocracia federal brasileira (1995-2014): avanços e dilemas. Revista de Administração Pública, 51(1), 1-26.

Constituição da República Federativa do Brasil, de 5 de outubro de 1988. (1988). Brasília, DF.

Cunha, B. Q. (2017). Os "regulocratas": características corporativas e implicações sistêmicas do funcionamento da burocracia das agências reguladoras no Brasil. In J. M. P. Paula, P. L. M. Palotti, P. L. C. Cavalcante, \& P. A. Alves (Orgs.), Burocracia federal de infraestrutura econômica: reflexões sobre capacidades estatais (pp. 217-251). Brasília, DF: Instituto de Pesquisa Econômica Aplicada.

Escola Nacional de Administração Pública. (2014). Federal civil servants: profile. Brasília, DF: Ed. Enap.

Evans, P., Rueschmeyer, D., \& Skocpol, T. (Orgs.). (1985). Bringing the State back in. Cambridge, England: Cambridge University Press.

Fernandes, C. C. C. (2015). Carreiras, profissionalização e construção do serviço civil na administração pública do Brasil: um desenho coerente? In Anais do $20^{\circ}$ Congresso Internacional do Centro Latino-Americano de Administração para o Desenvolvimento. Lima, Peru.
Fernandes, C. C. C., Silva, M. S., Cunha, B. Q., \& Alves, P. A. (2017). Arranjos institucionais e a burocracia de infraestrutura: notas para uma história sobre a construção das capacidades estatais no Brasil. In J. M. P. Paula, P. L. M. Palotti, P. L. C. Cavalcante, \& P. A. Alves (Orgs.), Burocracia federal de infraestrutura econômica: reflexões sobre capacidades estatais (pp. 61-113). Brasília, DF: Instituto de Pesquisa Econômica Aplicada.

Field, A. P. (2009). Discovering statistics using SPSS: and sex and drugs and rock ' $n$ ' roll (3rd ed.). London, England: SAGE.

Firmino, C. R., \& Silva, F. H. E. (2015). Desigualdades de gênero no serviço público do Poder Executivo federal. In A. Freire, \& P. Palotti (Orgs.), Servidores públicos federais: novos olhares e perspectivas. Brasília, DF: Escola Nacional de Administração Pública.

Fukuyama, F. (2013). What is governance? Governance, 26(3), 347-368.

Kjaer, M., Hansen, O. H., \& Thomsen, J. P. F. (2002, April). Conceptualizing State Capacity (DEMSTAR Research Report No. 6). Aarhus, Denmark: Aarhus University.

Leftwich, A. (1995). Bringing politics back in: towards a model of the developmental State. Journal of Development Studies, 31(3), 400-427.

Levi-Faur, D. (2011). From big government to big governance? Jerusalem Papers in Regulation and Governance, 35, 1-24.

Lopez, F., Bugarin, M. S., \& Bugarin, K. S. S. (2015). Mudanças político-partidárias e rotatividade dos cargos de confiança (1999-2013). In F. Lopez (Org.), Cargos de confiança no presidencialismo de coalizão brasileiro (pp. 33-70). Brasília, DF: Instituto de Pesquisa Econômica Aplicada.

Lopez, F., \& Praça, S. (2015). Critérios e lógicas de nomeação para o alto escalão da burocracia federal brasileira. In F. Lopez (Org.), Cargos de confiança no presidencialismo de coalizão brasileiro (pp. 107138). Brasília, DF: Instituto de Pesquisa Econômica Aplicada.

Mann, M. (1988). States, war and capitalism: studies in political sociology. Oxford, England: Blackwell.

Martins, L. (1975). Estado capitalista e burocracia no Brasil pós-64. São Paulo, SP: Paz e Terra. 
Matthews, F. (2012). Governance and State capacity. In D. Levi-Faur (Org.), The Oxford handbook of governance (pp. 281-293). Oxford, England: Oxford University Press.

Milward, H. B., \& Provan, K. G. (2000). Governing the hollow State. Journal of Public Administration Research and Theory, 10(2), 359-380.

Ormond, D., \& Löffler, E. (1999). A nova gerência pública. Revista do Serviço Público, 50(2), 67-97.

Palotti, P., \& Freire, A. (2015). Servidores públicos federais: novos olhares e perspectivas (Caderno ENAP n. 42). Brasília, DF: Escola Nacional de Administração Pública.

Paula, J. M. P., Palotti, P. L.M., Cavalcante, P. L. C., \& Alves, P. A. (Orgs.). (2017). Burocracia federal de infraestrutura econômica: reflexões sobre capacidades estatais. Brasília, DF: Instituto de Pesquisa Econômica Aplicada.

Peters, B. G., \& Pierre, J. (1998). Governance without government: rethinking public administration.
Journal of Public Administration Research and Theory, 8(2), 223-244.

Praça, S., Freitas, A., \& Hoepers, B. (2012). A rotatividade dos servidores de confiança no governo federal brasileiro, 2010-2011. Novos Estudos CEBRAP, 94, 91-107.

Quintella, R. H., \& Costa, M. A. (2009). O setor de telefonia móvel do Brasil após o SMP: as estratégias das operadoras e a convergência fixa-móvel. Revista de Administração Pública, 43(1), 123-150.

Riain, S. O. (2004). The politics of high-tech growth: developmental network States in the global economy. Cambridge, England: Cambridge University Press.

Tilly, C. (Org.). (1975). The formation of national States in Western Europe. Princeton, NJ: Princeton University Press.

Weiss, L., \& Hobson, J. (1995). States and economic development: a comparative historical analysis. Cambridge, England: Polity Press.

\section{Ciro Campos Christo Fernandes}

\section{https://orcid.org/0000-0002-6344-9169}

$\mathrm{PhD}$ in Administration from the Brazilian School of Public and Business Administration of the Fundação Getulio Vargas (FGV EBAPE); Professor of the Professional Master in Governance and Development of the National School of Public Administration (ENAP); Civil servant in the career of Specialist in Public Policy and Governmental Management in Brazil.E-mails: ciro.fernandes@uol.com.br; ciro.fernandes@enap.gov.br

\section{Pedro Lucas de Moura Palotti}

https://orcid.org/0000-0002-9071-9726

$\mathrm{PhD}$ in Political Science from the Institute of Political Science of the University of Brasilia (IPOL/ UnB); Professor of the Professional Master in Governance and Development of the National School of Public Administration (ENAP); Researcher at the Institute of Applied Economic Research (IPEA); Specialist in Public Policy and Government Management at the Federal Administration of Brazil. E-mail: pedropalotti@gmail.com 